ppi $201502 Z U 4645$

Esta publicación científica en formato digital es continuidad de la revista impresa ISSN-Versión Impresa 0798-1406 / ISSN-Versión on line 2542-3185Depósito legal pp $197402 Z$ U34
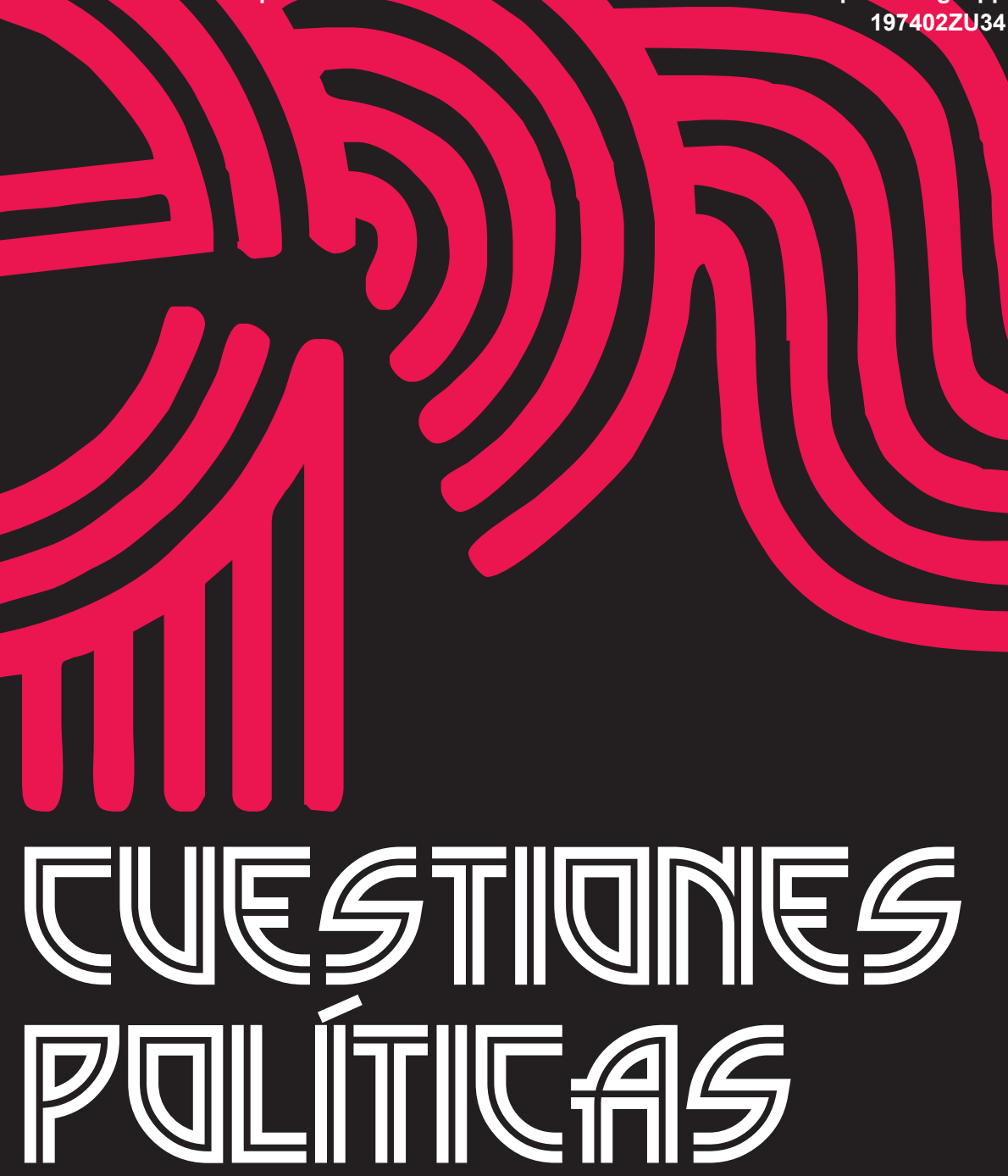

Instituto de Estudios Políticos y Derecho Público "Dr. Humberto J. La Roche" de la Facultad de Ciencias Jurídicas y Políticas de la Universidad del Zulia Maracaibo, Venezuela
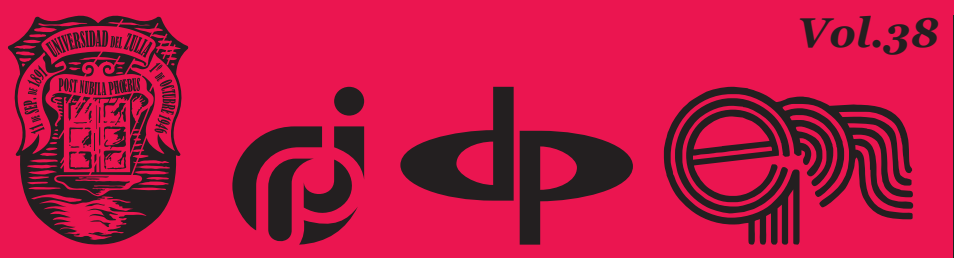

$N^{\circ}$ Especial 2da Parte 2020 


\title{
Taxonomy of compulsory and incentive legal consequences (legal measures) of committing illegal acts
}

\author{
DOI: https://doi.org/10.46398/cuestpol.382e.11
}

\author{
Oleksandr V. Kozachenko * \\ Olesia K.Vasyliaka ** \\ Larysa V. Chornozub *** \\ Olha M. Musychenko ****
}

\section{Abstract}

The article is prepared for the purpose of publishing the results of scientific research obtained in the process of applying the taxonomic methodology for systematization of measures of legal influence. The methodology used the approaches of philosophical and legal theorization, a dog and systemic functional. One way of conclusion is proposed for the first time to use the taxonomies of legal measures. The study highlighted three aspects of legal measures: relational, predicate and functional. The relational manifestation of taxonomy allowed to identify the substrate of the external form of legal influence, which is the measure. It has been established that the form and method of legal influence is the dominant element of each legal measure. The predicative dimension of taxonomy allowed to form a taxonomic system of information in which the following taxonomic categories and taxa are distinguished: type - social events; subtype - legal measures; class - public and private legal measures; gender - separation of legal measures according to their sectoral affiliation; subgenre: the allocation of incentives and coercive measures; supervision legal measures in their various forms and other measures that have no signs of legal liability.

* $\quad$ Doctor of Law, Professor, Head of the Department of Criminal Law and other criminal and legal studies of the Mykolaiv Institute of Law National University «Odessa Academy of Law» (Mykolaiv, Ukraine). ORCID ID: https://orcid.org/oooo-0oo2-8412-8639. Email avk.criminal.law@gmail.com

** Candidate of Law, Associate Professor of the Department of Criminal Law and other criminal and legal studies of the Mykolaiv Institute of Law National University «Odessa Academy of Law» (Mykolaiv, Ukraine). ORCID ID: https://orcid.org/oooo-0002-1280-2743. Email vok1321@ukr.net

*** Candidate of Law, Associate Professor of the Department of Criminal Law and other criminal and legal studies of the Mykolaiv Institute of Law National University «Odessa Academy of Law» (Mykolaiv, Ukraine). ORCID ID: https://orcid.org/oooo-ooo2-2819-9192. Email Loroch-ka@i.ua

**** Senior Lecturer of the Department of Criminal Law and other criminal and legal studies of the Mykolaiv Institute of Law National University «Odessa Academy of Law» (Mykolaiv, Ukraine). ORCID ID: https://orcid.org/oooo-ooo1-6171-710X. Email musychenkoolga@gmail.com 
Oleksandr V. Kozachenko, Olesia K.Vasyliaka, Larysa V. Chornozub y Olga M. Musychenko Taxonomy of compulsory and incentive legal consequences (legal measures) of committing illegal acts

Keywords: taxonomy; substrate of the legal measure; taxon taxonomic categories (ranges); classification of legal measures; alternative legal studies.

\section{Taxonomía de las consecuencias legales obligatorias e incentivadoras (medidas legales) de cometer actos ilegales}

\section{Resumen}

El artículo está elaborado con el propósito de publicar los resultados de la investigación científica obtenidos en el proceso de aplicación de la metodología taxonómica de sistematización de medidas de influencia jurídica. En lo metodología se utilizaron los enfoques de la teorización filosófica y jurídica, análisis dogmático y funcional sistémico. A modo de conclusión se propone por primera vez utilizar las taxonomías de medidas legales. El estudio destacó tres aspectos de las medidas legales: relacional, predicado y funcional. La manifestación relacional de la taxonomía permitió identificar el sustrato de la forma externa de influencia jurídica, que es la medida. Se ha establecido que es la forma y método de influencia jurídica el elemento dominante de cada medida legal. La dimensión predicativa de la taxonomía permitió formar un sistema taxonómico de información en el que se distinguen las siguientes categorías taxonómicas y taxones: tipo - eventos sociales; subtipo - medidas legales; clase - medidas legales públicas y privadas; género - separación de medidas legales de acuerdo con su afiliación sectorial; subgénero: la asignación de incentivos y medidas coercitivas; supervisión - medidas legales de responsabilidad legal en sus diversas formas y otras medidas que no tienen signos de responsabilidad legal.

Palabras clave: taxonomía; sustrato de la medida legal; taxón categorías taxonómicas (rangos); clasificación de medidas legales; estudios jurídicos alternativos.

\section{Introduction}

Law, playing the role of a universal regulator of public relations, is not least focused on the exercise of normative influence in the case of delicts, which has two interconnected forms. On the one hand, on the internal side, legal influence is associated with the formation of an appropriate 
level of legal consciousness, legal culture, which form the person's internal guidelines for proper behavior, and on the external side, influence on the person is carried out through the use of special legal tools.

Modern law is characterized by a wide range of methods of exercising the necessary legal influence on a person with tort behavior, as well as the number of legally defined regulators of public relations that use such techniques. The increase in the number of measures that are applied in law is due to the general tendency to form a significant number of new branches of law, which are determined primarily by the specific characteristics of social relations to be regulated, that is, the subject of legal regulation and, secondly, by the simultaneous process of splitting up the so-called "classical" branches of law, as a result of which the new legal formations "tend" to the use of their own, specific methods.

Thus, a significant number of branches of law, new intersectoral and complex legal formations have introduced into modern legal regulation a significant number of not sufficiently studied new measures, which, in the conditions of further specialization of legal theory and practice, have not become the subject of general legal research and unification, which negatively affects modern legal doctrine, normative certainty and the practice of applying legal regulations. These trends require modern legal science to conduct a rigorous and detailed revision of all legal measures, to carry out their necessary classification and systematization, taking into account social conditionality, the admissibility of their application and to determine the functional effectiveness in solving their tasks. We consider the use of the taxionomie of legal measures to be the most acceptable way to achieve the set and other secondary goals.

The publication was prepared with the aim of highlighting the results of the scientific search for new foundations for the implementation of classification and systematizing measures of legal influence on persons who committed acts with signs of tort, for which a taxionomic approach is used with the isolation of the substrate of legal influence, which has certain essential properties (taxionomic attributes) of a general and universal nature.

\section{Theoretical framework}

The theoretical basis of the study was a new conceptual approach to the general and universal nature of influence applied on a legal basis, which takes on certain features in various areas of law, depending on the subject and method of legal regulation by which these branches of law are distinguished. 
Oleksandr V. Kozachenko, Olesia K.Vasyliaka, Larysa V. Chornozub y Olga M. Musychenko Taxonomy of compulsory and incentive legal consequences (legal measures) of committing 154 illegal acts

It should be noted that recently attempts have been made to define a system of legal measures, and only within certain branches of law (Humin, 2013; Dembitska, 2018; Ponomarenko, 2020; Puhach, 2018; Tymchenko, 2012; Yaremko, 2014), however, most research in this area is not based on the definition of an activity as a substrate of an external form of legal influence, which is universal, does not take into account the obvious systemic elements and the general social orientation of the functions carried out in the process of applying legal measures.

The application of taxionomic systematization allows at the general social level: to obtain an overall picture of legal measures of influence, ensuring: first, to obtain a complete and exhaustive list of measures that are used by the State as responses to social challenges in the form of tort behavior and other legal grounds for applying legal measures of deviation; secondly, to form a general idea of the hierarchical nature of legal measures on the principles of distinguishing their essential properties; thirdly, to create the ground for identifying systemic links between taxa of different taxionomic ranks (categories); fourthly, clearly delineate the scope of possible legal measures depending on the taxionomic rank (category): type, class, type and type of legal measures; fifth, to ensure the formation of harmonized sectoral legislation taking into account the peculiarities of the ranks of taxa and their content; sixth, to correct errors made as a result of inconsistent rulemaking and the determination of prospects for further law-making activities, taking into account the social order and the functions of legal measures; seventh, to predict the prospects for the further use of polytype taxa with the possibility of expanding or narrowing their functional potential, including in the search for an adequate response from the state to various social challenges.

The results of the study at the general theoretical level allow: firstly, the formation of the concept of a legal measure; secondly, to conduct an enforcement audit with a clear distinction between legal responsibility and other legal measures that do not have the characteristics of liability; thirdly, to identify among all the features and properties of measures of influence that form taxa of a typical nature and those that are atypical; fourthly, among all essential properties, to distinguish those having an objective (conditionally objective) and having a subjective (conditionally subjective) character; fifth, to determine the discrete nature of the substrate content of legal influence. At the sectoral and institutional level, the study will ensure the development of terminology consistent for all branches of legal knowledge related to the exercise of influence on a person in connection with his unlawful behavior. 


\section{Methodology}

The formation of a new conceptual model of legal measures in their system requires an expansion of the methodological basis of legal research, which corresponds to modern approaches to the implementation of effective scientific search. In today's conditions, when choosing the methodological basis for conducting scientific research, humanitarian methodology has gained a significant spread, but positivism (scientific and natural) direction has not yet exhausted its potential.

The choice of the direction of scientific research predetermined the search for appropriate scientific tools capable to solve the problems posed in the process of scientific analysis. Among all possible methods of scientific knowledge, preference was given to taxonomy, which is knowledge of a system of concepts in their systematization. Taxonomy, being a theory of the classification of complex structures, has become widespread in various spheres of human life: in biology in the process of classification and systematization of living beings and organisms, in physics in connection with the fixation of the existence of a large number of fundamental particles, in chemistry in connection with the necessity to order chemical elements, in education in the search for optimal forms of assimilation of scientific material, and so on.

In the choosing a methodology, we proceed from the fact that taxonomy in a broad sense is not limited exclusively to the definition, description and nomenclature of the researched objects, but also includes a system of knowledge regarding the methodological foundations of the implemented classification and systematization. Such an understanding of taxonomy makes it possible to ensure its effective use in theoretical and applied jurisprudence, since one of the important elements of the latter should be recognized as a set of legal measures of influence on human behaviour. legal measure, in turn, is characterized by internal and external architectonics. Taxonomy in relation to the internal structure of a legal measure allows to highlight the essential features and properties inherent in each legal measure. The use of taxonomy in the process of studying the external architectonics of legal measure ensures the formation of a system of legal measure, regardless of the branch of law or legal institution to which such measures are related.

The application of taxionomie in the process of implementing the systematization of legal measures makes it possible to solve the set scientific tasks and achieve certain goals by applying a wide range of general and special methods of scientific knowledge, among which the following should be mentioned separately. The method of philosophical and legal theorization provides for the definition of stages of categorical understanding of the nature of the exercise of legal influence. 
Oleksandr V. Kozachenko, Olesia K.Vasyliaka, Larysa V. Chornozub y Olga M. Musychenko Taxonomy of compulsory and incentive legal consequences (legal measures) of committing 156 illegal acts

\section{Results and discussion}

Modernity poses new global challenges to humankind, which, in addition to the traditional ones, require a solution. Basically, the answers to emerging and existing permanent challenges are found in the legal sphere, since the right itself is distinguished among all regulators of public relations by general obligation. Law today is a multifunctional design, the components of which, among many other tasks, provide for the use of a special type of toolkit - legal measures, the number of which is constantly growing with geometric progress. Thus, the present requires the search for innovative approaches to modulating a system of legal measures, since traditional ways of systematization, which are used in the context of deepening existing intersectoral dissociations, that sometimes they acquire signs of antagonistic contradictions, do not allow for the effective classification and systematization of the totality of existing legal measures with the possibility of predicting the inclusion of new tools to ensure the proper behavior of a person through the application of external forms of legal influence.

The scientific feasibility of using taxionomy is related to the need to study the multidimensional legal realities that are legal measures to be applied to torturers, with the identification of the essential properties of such measures and subsequent consideration in the process of their systematization. It is taxionomie that creates the prerequisites for the scientifically sound systematization of all various sectoral and institutional groups of legal measures that are the legal consequence of the commission of a socially dangerous act in various forms of its manifestation.

Taxionomie, acting as a theory of classification of complex structures and therefore becoming widespread in biology for the systematization of organisms and living things, in physics - in the process of ordering elementary fractions, in chemistry - in the systematization of chemical elements, in education - in the process of forming professional competence, etc., is also used in theoretical (Sherwin, 2009) and butt (Tuliakov, 2011; Melnichuk, 2016), since one of the important elements of the latter is the set of legal measures to influence the behavior of a person, each of which and the set as a whole are characterized by internal and external architectonics.

The sphere of application of the taxionomic approach is traditionally considered to be natural space, consisting either of natural objects or artificial realities that reproduce natural processes and laws (Shatalkyn, 2012). Based on the fact that legal measures should be attributed to natural space on the second basis, which will be proved later in the process of studying the essential properties of legal measures, we conclude that the object of systematization is such legal realities that have not random, but logical characteristics, which not only allows, but also significantly increases 
the significance of the proposed approach of implementing the taxionomy of legal measures.

Legal measures, as a separate socio-legal entity, are characterized by many aspects, attention to which is determined by the goal of scientific search. In the context of our scientific analysis, three aspects of the subject matter should be emphasized. Firstly, legal measures in a relational meaning, which is associated with the definition of the "first element," the substrate of social and legal reality, which is at the heart of systematization. The relational image of the entity requires the focus of scientific search on the definition of taxionomic attributes that recognize the essential properties of the substrate, their position as the basis of the systematization carried out and the solution of the main problem, which consists in the isolation of the paths and results of changes passing through the substrate before forming the entity with its inherent systemic connections. Secondly, the essence in the predicative dimension is expressed through a system of typical, generic, species features that form the basis for the construction of a formalized model consisting of taxionomic ranks (categories) for which legal measures are distributed on the basis of their common substrate properties and individual characteristics that indicate their homogeneity, which thirdly, the functional manifestation of the essence reflects the dynamic aspect of legal measures, which reproduces the instrumental suitability of measures for solving their tasks and reflects their effectiveness in achieving the common goal and special goals of individual taxa.

As already noted, the relational essence of legal measures is associated with their substrate, which is "measure." This term, despite a fairly long doctrinal and normative application, which is not limited exclusively to certain branches of law in which tort relations are considered basic, is perceived as an intuitive category and therefore does not require a strict legal definition.

Emphasizing the need to use the previously mentioned approach (Kozachenko, 2011) before the definition of the action as a substrate of all forms of implementation of social and right-wing influence, it should be noted that it is advisable to mean an element of social and legal regulation of tort and related relations, which meaningfully combines a system of methods and ways of implementation of forced and incentive impact, used to obtain a positive socially significant result.

Thus, any activity that represents the external expression of the social and legal impact carried out has the following features. Firstly, the measure, being applied in the legal sphere, acts as a regulator of legally significant behavior that has signs of tort, or behavior directly related to torts, for example, provided for by the law of deviation, post-delict behavior. It should be noted separately that the law sometimes covers the application of the category of restraint and the means of securing the obligations assigned 
Oleksandr V. Kozachenko, Olesia K.Vasyliaka, Larysa V. Chornozub y Olga M. Musychenko Taxonomy of compulsory and incentive legal consequences (legal measures) of committing 158 illegal acts

to the person, which cannot be considered sufficiently reasoned, since in this case it is a method of ensuring that the regulatory requirements for the proper conduct of the person are met. Secondly, each legal measure represents a set of ways and methods of legal influence. Two distinct but naturally related ways of exercising legal influence - encouragement and coercion - are traditionally considered to be legally relevant (Robinson, 1997).

The first of these modes of exposure generally depends on the will of the person under legal influence, and the second indifferent to the desire of the person to be subject to such influence. Encouragement and coercion form two possible patterns of treatment of the person who is exposed: voluntary and coercive behaviour. Given the fact that the paradigm of modern social and legal regulation is based on the principles of anthropodicy (Kozachenko, 2009), which presents a person, his interests to the level of the core factor of social being in various forms of its existence, including a legally significant dimension, should be emphasized the priority of encouragement over coercion.

Thus, the measure of legal influence should contain either exclusively encouragement to a certain type of conduct or encouragement and coercion, the latter being applied only if the subject under legal influence does not fulfil the legitimate requirements voluntarily. In turn, the method of legal influence reflects the characteristics of the measure, which indicate its peculiarity, specificity, difference from other measures. Ways and methods of legal influence are the dominant of any measure, and the methods determine the method by which the influence will be carried out in the process of application of the measure, and the methods reflect the nature and content of such influence. Thirdly, legal measures are geared towards making a positive impact as a response to the commission of delicts and other related deviations.

Along with the features, each legal measure has properties that are significant (in ontological meaning) and play the role of taxionomic attributes for the reasoned systematization of legal measures in particular and taxionomie in general. All characteristics inherent in a legal action that are essential for achieving the goal of taxionomic classification and systematization can be conditionally divided into those of a generally objective and generally subjective nature. The classification of certain properties as objective or subjective is carried out taking into account the view of the right as a system of norms, ideas and relationships that ensure the purpose of social activity, forming certain stereotypes of behavior that receive social approval on the basis of recognition of their compliance with human expectations.

One of the objective characteristics of a legal measure, which reflects the orientation of the effect of its application, should be recognized as 
the purpose of the legal effect. We believe that, given the dominance of the rule of law, social justice should be recognized in order to exercise legal influence in its external form. It is well known that social justice is a fundamental element of social relations, which derives from the equal and just opportunities of each individual to realize his social potential. In general, the category of justice, unlike other guidelines of consciousness, provides not a simple assessment of a particular social phenomenon (good or evil, true or untrue), but a ratio of several (two or more) characteristics between which it is necessary to establish ethical correspondence.

Thus, the correspondence between a decent act and the reward that such an act deserves, between the immoral behavior of a person and various forms of social condemnation and the internal experiences of a person, between behavior that violates corporate requirements, and the corresponding measures of influence of corporate entities and the like is considered equitable in social significance. Thus, fairness reflects the idea of the right, proper order of things in social relations, which corresponds to the ideas about the appointment of a person, his natural and inalienable rights and duties, the social validity of the interests of the holder of rights and duties (Miller, 1999; Sen, 2009).

At one time, one of the apologists for the widespread application of social justice as a paradigm not only of the legal, but also of the general social existence of man, Aristotle (Aristotle, 2000) proposed to characterize justice as a certain reimbursable, equalizing and distributive state, which is formed as a result of the implementation of various forms of influence on personality. This was a prerequisite for highlighting three components of social justice. Reimbursable social justice is characteristic of a situation in which retaliation for a violation is fully consistent with the nature of the violation committed by the person. It should be emphasized that the entire history of mankind, in its legal aspect, is connected with the search for criteria for compensatory justice, one of the ancient examples of which is the talion.

Distributive or distributive fairness determines the conditions for the distribution of social values claimed by the person or the legal consequences applied in connection with the unlawful behavior of the person, in accordance with the social role played by the subjects of the relationship. In turn, equalizing, or retributive, justice depends on the virtues, victories or other socially significant qualities of each person. A striking example of the implementation of all components of social justice is the imposition by the court of punishment for a crime committed by a person (Robinson et al., 2010). In particular, in the process of choosing a type and measure of punishment, the court forms the basis of retaliation for a criminal act, distributive justice is manifested in the individualization of punishment depending on the role played by each offender in the process 
Oleksandr V. Kozachenko, Olesia K.Vasyliaka, Larysa V. Chornozub y Olga M. Musychenko Taxonomy of compulsory and incentive legal consequences (legal measures) of committing

of committing a socially dangerous act (organizer, perpetrator, instigator, etc.), and retributive justice is manifested in an individual assessment of the signs characterizing the identity of the offender (presence of a preliminary criminal record, commission of an act intoxicated, etc.).

In the legal field, these general signs of social justice take on unique characteristics and are manifested, in particular, in accordance with the relationship between rights and obligations, between labour and remuneration, between acts and giving, etc. And under the dominance of the rule of law, social justice in tort relations is multidimensional and, in particular, manifests itself in accordance with the following: socially dangerous act and coercive legal measures that apply to the perpetrator; damage caused by losses and restorative and compensatory measures; positive post-delict behaviour and rehabilitation and incentive measures. At the same time, the basic provision for determining various manifestations of social justice in the process of applying legal measures is a focus on the search for coherence between the interests of a person, society and the state (Kozachenko and Musychenko, 2015). Accordingly, the application of legal measures should be accompanied either by the restoration of the state of social justice, which was violated by a committed act with signs of tort, achieved by the application of mainly coercive legal measures, or by the formation of a state of social justice by the application of incentive legal measures based on the results of a fair assessment of the person's postdelict behavior.

The properties of legal measures with an objective nature include the grounds for their purpose. All the grounds on which legal measures can be imposed can be divided into two groups: general and special. The first group includes the commission of an act for which one of the main types of legal measures can be assigned. The main legal measures should include those that are designated only as stand-alone and under no circumstances can they join in addition to other legal measures. In turn, special grounds for the designation of legal measures include those acts for which only additional legal measures are prescribed by adding them to the main legal measures of influence and therefore cannot be applied independently.

The general grounds for the application of legal measures include, first, the commission of a legal tort, which means misconduct containing signs of a guilty, unlawful and socially harmful act committed by a sensitive person and a legal consequence for which the law provides for the application of legal responsibility; secondly, an objectively wrongful act (quasi-identity), which contains all or several signs of a legal tort for lack of signs of a person's sensitivity (commission of an act by an insane person, a person who has not reached the age of legal responsibility, but is provided for the possibility of applying juvenile legal measures, etc.). 
Special grounds for the application of legal measures include any special but necessarily statutory preconditions for the imposition of additional legal measures, for example, abuse of law as a basis for the application of special medical measures to persons who abuse alcohol or narcotic substances, positive post-delict behavior in the form of voluntary compensation for damage caused, as a basis for exempting a person from further legal liability, and the like. In turn, special grounds for the designation of legal measures can be classified depending on whether they are grounds for the application of coercive legal measures and which are of the nature of other deviations, and those that are grounds for the application of incentive legal measures. It should be noted separately that special grounds can be provided by law and in the form of a certain, legally defined condition - pregnancy, mental disorder, and even a certain event. Thus, for example, the expiration of the statute of limitations for bringing a person to legal liability is the basis for exempting a person from such liability for a legal offence committed.

The characteristics of legal measures with a subjective nature are expressed in the circle of persons against whom such measures are applied. It should immediately be emphasized that the scope of legal measures is much wider than those who are recognized as the subject of the offence and to whom legal liability can apply. With this in mind, all subjects of legal measures may be classified into general - subjects of legal delicts to which legal liability measures may apply, and special ones, which in turn are divided into two groups: persons who do not have all the characteristics inherent in a fully sensitive person - sanity, reaching the age of responsibility, etc., and persons who, in accordance with the requirements of the law, must have additional to the general characteristics, properties or characteristics persons who are obliged to compensate for damage caused by the subject of the tort, stateless persons for whom extradition is possible, etc.

A separate subjective characteristic of legal measures should be recognized as its procedural component, which ensures the choice of legal measure among those whose list is determined by law taking into account the specificity of the act itself and the person who committed it. The procedural aspect of subjective properties of legal measures finds the reflection in a procedural discretion (procedural diskretion) as which it is necessary to understand intellectual and strong-willed activity of the authorized subject appointing a legal measure, being guided by provisions of the material and procedural legislation, and consists in the reasonable and impartial choice of socially fair decision regarding application of legal measures.

Current trends in legal doctrine that relate to the solution of rightwing issues in the process of legal regulation, Indicate that the application of legal measures should be carried out in order to ensure the necessary and sufficient impact, the nature and size of which is determined on the basis of the internal conviction of those persons, which are entitled to an 
Oleksandr V. Kozachenko, Olesia K.Vasyliaka, Larysa V. Chornozub y Olga M. Musychenko Taxonomy of compulsory and incentive legal consequences (legal measures) of committing

appropriate procedural right as a result of the impartial, objective and fair determination of all the circumstances of both the act and the person against whom the legal measure is applied.

Thus, the taxionomie, in its relational meaning, is the study of the legal measure on its essential properties, in order to determine the substrate, the signs of which are constant and therefore serve as the only criterion for assigning various forms of legal effect to legal measures.

If the relational aspect of taxionomy is based on the certainty of the taxionomy object through its essential properties, then the predicate requires classification - the distribution of objects into certain groups, taking into account the significant and additional properties of the object and the systematization that is associated with bringing objects into the system in accordance with the connections that exist between them. The result of applying taxionomy in its predicate meaning is an information taxionomic system, which can be presented in the following form.

The vertex of an information taxionomic system should be recognized as a taxionomic category - a type that reflects the maximum level of generalization that has a corresponding description. In general, the type acts as a kind of model, a standard that determines the nature of the information taxionomic system as a whole, its basic structuring. A peculiar archetype of the entire system is the event as an external manifestation of the social impact carried out, but the subtype should be recognized as its legal form, which, next to other social forms, such as moral and ethical, customary, religious and the like, determine the content of the doctrine of really general.

The next level of taxionomic hierarchy is the class of legal measures, which is characterized by an additional property that can provide an objective distribution of measures to taxa that simultaneously meet the requirements of a certain subtype. We believe that all activities of the legal subtype can be divided into two classes, which are characterized by the presence or absence of etatist features and therefore this class of public legal activities (the etatist component in such activities is dominant) and private legal measures (measures of legal influence of this class are in the sphere of interests of entities that are not vested with public powers). Given the certain conditional division of legal measures into classes, which is of the same nature as the division of law into public and private, the allocation of this taxionomic category plays an important role in the formation of a hierarchical system of legal measures, depending on the role played by the State in the person of its organs and officials during the exercise of legal influence.

Next in the direction of reducing generalization is the taxionomic category of the genus, which covers the multiplicity endowed with certain additional 
properties. The taxon of the kind is more consistent with systematization, which is traditional for modern general theoretical jurisprudence and consists in the allocation of individual branches of law. Along the way, it should be emphasized that the properties that ensure the formation of branches of law should be recognized as the subject (a special group of social relations that are subject to the regulatory influence of law) and the method (ways of implementing legal regulation by combining mandatory, encouraging, ascribed, advisory and other paradigms). Given the fact that legal measures have a combination of modes of influence (coercion and encouragement), all taxon measures of the kind have a complex structure (polystructure), which reflects industry affiliation and the mode of influence dominant in a particular activity.

The basic taxon should be recognized as a type that also has a polystructure, which is caused by the many signs of legal measures to be taken into account in order to create a hierarchical model convenient for use. The taxon of a type structurally consists of a review, a type and a subspecies of legal measures. The heading covers measures that are divided into legal liability measures and other measures. Legal responsibility should be recognized as a type of social responsibility that has legal certainty (certainty in law) and is endowed with a state-power character and manifests itself in the restriction of the rights and freedoms of the subject, which the person did not experience if he behaved lawfully and did not commit an offense. At the same time, legal liability and its implementation are carried out in accordance with the procedure established by law, with compliance with all the requirements provided for by regulatory regulations. The process of implementing this type of responsibility is connected with the issuance by the state body of an act of application of a rule of law (law enforcement act), according to which responsibility is carried out, that is, realized. The special procedural form (procedure) of the exercise of legal responsibility is a guarantee of objective consideration of the committed and assessment of both the act and the person who committed it.

The species combines activities that are distinguished by a unique means of legal influence, which distinguishes one legal event from another within the taxionomy of the genus. For example, if examples of criminal proceedings were to be continued, conviction, punishment and criminal record should be recognized as criminal measures if they were provided for by national criminal law. Other types of criminal law measures include medical, juvenile, restrictive, legal persons, etc., provided that they are provided for in criminal law.

Polytype (multi-view) measures form subspecies of legal measures. For example, punishment, as a type of public legal measure of criminal liability, is inherent in such separate subspecies as fine, deprivation of liberty, confiscation and the like. In turn, activities in relation to legal entities, as 
Oleksandr V. Kozachenko, Olesia K.Vasyliaka, Larysa V. Chornozub y Olga M. Musychenko Taxonomy of compulsory and incentive legal consequences (legal measures) of committing 164 illegal acts

a public law class of activities that do not have signs of criminal liability, include such subspecies as confiscation, liquidation and the like. Monotype (single-type) legal measures, on the example of criminal legal measures, are such measures as special confiscation, compulsory treatment of persons suffering from drug addiction, etc., the variation of the methods of their influence is not characterized.

Thus, taxionomie in predicative meaning is a way of knowing the external forms of legal influence, which allows you to form an information taxionomic system built on a hierarchical basis, where each taxon is determined by the existing connections with those that are both in front of it and those that follow it.

In turn, the functional manifestation of the essence of legal influence justifies the existence of the functional sphere of taxionomy. In general, the application of the etymological approach convinces that the term "function" comes from the Latin "functio" - activity, duty, work, purpose (Modern Philosophical Dictionary, 1998). From the philosophical point of view, which was formed in connection with the application of this term:

\footnotetext{
Preceding jurisprudence, the function is the internal and external relations of a certain system, which are a stabilizing factor that ensures the relative stability of both the system itself and the relations with other systems. Thus, a function in philosophical meaning is the external manifestations of the internal properties of any object or phenomenon in a certain system of relations. The active application of the term "function" in the theory of law ensured the formation of a legal concept, which is mainly interpreted as the main direction, subject and content of legal influence that determines the instrumental suitability of law (Kozachenko, 2017: 25).
}

To define the functional scope of the taxionomy of legal measures as a special form of external legal influence on persons who have committed a tort or other forms of deviant conduct prescribed by law, the following should be taken into account. Firstly, the chosen approach to the classification and systematization of legal measures focuses on the need to determine the goals of their application, which should correspond to the general goal of their normative purpose - restoring the violated state of social justice or forming a state of social justice. So, for example, as the purposes of application of criminal measures it is necessary to recognize an execution, correction, prevention, re-education, delivery of health care and treatment of persons, a restitution and compensation, rehabilitation, encouragement, etc., each of which is "an ideal image of the expected result in the settled public relations" (Kozachenko, 2011: 282). 
Secondly, the content of activities in the process of carrying out the functions of legal measures, being derived from the appointment of such activities, should be historically and culturally conditioned. Not only the need for regulatory influence on social relations, but also the forms and content of influence themselves are determined by the features of social development, generally recognized social values, and the conditions of social development (Kozachenko, 2017). Thirdly, the functions of legal measures derive from the general functions of law, presenting the defining properties of the latter and simultaneously interpreting them, providing them with the suitability to achieve the goals set for activities uniting within a certain taxon. The generalizing nature of the functions of law ensures that one function of law forms the basis of several functions of legal measures.

The punitive and preventive functions of criminal legal measures are set by the protection function of law, specifying the latter taking into account the characteristics of the subject, the goals and the nature of the criminal legal impact. In turn, the restitution, compensation, rehabilitation and incentive functions of criminal legal measures are determined by the regulatory dynamic function of law. Fourthly, the functions of legal measures are interconnected, create a certain legal regime for the legal regulation of public relations that arose as a result of the commission of a delict. Fifth, the functions of the legal measures of one taxon must not only correspond to the functions of the taxon that precedes, but also themselves are simultaneously a template for the functions of the following taxa. Sixth, certain types of legal measures have a polytype structure that ensures the multi-vector functioning of legal measures of a particular type (a special level of functioning).

Taking this into account, it can be concluded that taxionomie is functionally focused on the study of the functions of legal measures, which should be understood as the main areas of their legal influence on public relations, that arise in the course of the person committing delicts and other types of deviant behavior, which encroach on the system of social values, formed on the basis of the indisputable nature of recognition of natural human rights and freedoms and the peculiarities of the civilizational level of development of national culture, in order to restore or create a state of social justice, thereby creating a special legal regime against negative manifestations and ensuring the existence of the rule of law.

\section{Conclusions}

As a result of the research, the outstanding relational manifestation of the classification and systematization carried out, which is based on the recognition of the "measures" as a substrate, the first element of the 
Oleksandr V. Kozachenko, Olesia K.Vasyliaka, Larysa V. Chornozub y Olga M. Musychenko Taxonomy of compulsory and incentive legal consequences (legal measures) of committing

entire set of legal measures. Each legal measure is an external element of the social and legal regulation of tort and related deviant relations, which meaningfully combines a system of methods and ways of implementing coercive and encouraging influence, used to obtain a positive socially significant result. It is determined that the ways and methods of legal influence are the dominant component of each legal measures, while encouragement and coercion in their specific combination determine the method by which influence will be exercised during the application of the measures, and the methods reflect the nature, content of such impact.

The identified taxionomic attributes of both objective (purpose, grounds) and subjective (subject of application, procedural discretion) character ensured the solution of the problems of relational assignment of the proposed taxionomy of legal measures. The predicate dimension of taxionomy is associated with the formation of an information taxionomic system with the isolation of the following taxionomic categories and their corresponding taxa, which combine measures characterized by a certain degree of commonality: type - social measures; subtype - legal measures; class - public legal and private legal measures; genus - separation of legal measures in accordance with their sectoral affiliation; subgenus - the allocation of incentive and coercive measures; superview - legal measures of legal liability in various forms and other measures that do not have signs of legal liability; type - monotype and polytype legal measures defined by law; subspecies - structural elements of polytype legal measures. It was concluded that the functional aspect is derived from the general (strategic) purpose of legal measures and the specific purpose of individual legal measures.

\section{Bibliographic References}

ARISTOTLE. 2000. Policy / Translated from the Ancient Greek. A. Kysliuk. Fundamentals. Kyiv, Ukraine.

DEMBITSKA, Susanna Leonidivna. 2018. "Classification of administrative measures in the system of administrative coercion" In: State and regions. Series: Law. No 1 (59), pp. 71-76.

HUMIN, Alexey Mikhailovich. 2013. "System of measures to ensure criminal proceedings under the new Criminal Procedure Code of Ukraine" In: Scientific bulletin of the National Academy of Internal Affairs. No 1, pp. 226-231. 
KOZACHENKO, Oleksandr V. 2009. "Cultural dimension of the paradigm of modern criminal law” In: Law of Ukraine. No 5, pp. 121-126.

KOZACHENKO, Oleksandr V. 2017. Functions of criminal legal measures (cultural and anthropological approach). Modern criminal law: scientific essays: monograph / ed. N. A. Myroshnychenko, E.L. Streltsov; preface by S.V. Kivalova. Legal Literature. Odessa, Ukraine.

KOZACHENKO, Oleksandr V. 2011. Criminal legal measures: cultural and anthropological dimension: monograph. Ilion. Nikolaev, Ukraine.

KOZACHENKO, Oleksandr V; MUSYCHENKO, Olga Mykhailivna. 2015. Cultural and anthropological dimension of justice of criminal legal influence: world achievements and national achievements. Humanitarian discourse: politics, governance, power: collective monograph by general editing O. A. Ivakin, I.V. Shamsha, D.V. Yakovlev. Publishing House "Helvetika,". Odessa, Ukraine.

MELNICHUK, Tetiana Volodymyrivna. 2016. "Multi-material taxionomy of criminological knowledge" In: Bulletin of the criminological association of Ukraine. No 2 (13), pp. 131-142.

MILLER, David. 1999. Principles of Social Justice. MA, Harvard University Press. Cambridge, United Kingdom.

MODERN PHILOSOPHICAL DICTIONARY. 1998. / ed. Doctor of Philosophy, Professor V.E. Kemerov. Panprint. London; Frankfurt am Main; Paris; Luxembourg; Moscow. Minsk, Belarus.

PONOMARENKO, Yuriy Anatoliyovych. 2020. "Types of means of criminal law" In: Problems of legality. No. 149, pp. 154-167.

PUHACH, Andrew. 2018. "Classification of measures to ensure proceedings in cases of administrative offenses" In: Scientific bulletin of the Dnipropetrovsk State University of the Interior. No 2, pp. 99-104.

ROBINSON, Paul. 1997. Structure and Function in Criminal Law. Clarendon Press. Oxford, United Kingdom.

ROBINSON, Paul H; GOODWIN, Geoffrey; REISIG, Michael. 2010. "The Disutility of Injustice" In: New York University Law Review. Vol. 85, No. 6, pp. 1940-2033.

SEN, Amartya. 2009. The Idea of Justice. Cambridge (Mass). The Belknap Press of Harvard University. Cambridge, United Kingdom. 
Oleksandr V. Kozachenko, Olesia K.Vasyliaka, Larysa V. Chornozub y Olga M. Musychenko Taxonomy of compulsory and incentive legal consequences (legal measures) of committing illegal acts

SHATALKYN, Anatoly I. 2012. Taxionomie: Foundations, principles and rules. Society of Scientific Publications of KMK. Moscow, Russia.

SHERWIN, Emily. 2009. "Legal Taxionomy. Legal Theory" In: Cambridge University Press. Vol. 15, No. 1, pp. 25-54.

TYMCHENKO, Anatoly M. 2012. Types of coercive measures in tax law: dissertation. Candidate of Law Science. Kyiv, Ukraine.

TULIAKOV, Vyacheslav Alekseevich. 2011. Taxionomie of criminalization and criminal law. In: Man and the law: public legal dimension: collection of scientific works. edited by S.V Kivalov, V. A. Tuliakov, O. V. Kozachenko. Ilion. Nikolaev, Ukraine.

YAREMKO, Galina. 2014. "System of measures of a criminal legal nature" In: Chasopis of the Academy of Law of Ukraine. No. 4 (25), T. 7. Pp. 89-96. 

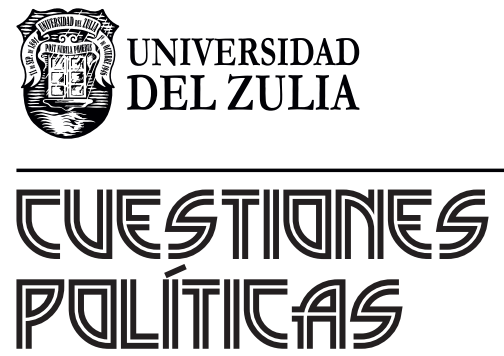

Vol.38 NEspecial

Esta revista fue editada en formato digital y publicada en diciembre de 2020, por el Fondo Editorial Serbiluz, Universidad del Zulia. Maracaibo-Venezuela 